\title{
Marketing Research of the Chocolate Market in Macedonia
}

\author{
Tamara Jovanov Marjanova
}

\section{INTRODUCTION}

\section{"The object of business is to create a customer." - Peter Drucker}

Economic development is a complex and multidimensional process that involves changes in the social culture, value system and national public and private institutions, but is primarily determined by economic growth and efficient allocation of resources. Republic of Macedonia is not isolated from the globalization changes and despite the fact that as a small economy it cannot have a huge impact on their total flow, at the same time it doesn't mean that it should occupy the role of a passive observer. We are a society of cheap labour, which dreams of becoming a society based on capabilities.

The so-called Information era justifiably considers that the greatest success in development will have those with the best strategy, strategy built on quality information, that creates the path for active involvement and monitoring of the current flows of globalization. The recession, although it seems that way, is not the time for deceleration and reduction of marketing activities, on the contrary, it is the time to increase and accelerate them. Those who are prepared to quickly and effectively carryout the plans are those that will win on the long run.

Marketing as a business philosophy is actually a process which is presumed to be found to satisfy and retain customers, and in another parallel to make profits from the operations, in which the central focus is on the consumer and his relationship with the product, i.e. his opinion whether the product / service can meet the need or desire. According to the American Marketing Association (http://www.marketingpower. com/AboutAMA/Pages/DefinitionofMarketing.aspx) "Marketing research is the function that links the consumer, customer, and public to the marketer through information - information used to identify and define marketing opportunities and problems; generate, refine, and evaluate marketing actions; monitor marketing performance; and improve understanding of marketing as a process...”.

Marketing research extends throughout the entire course of the marketing planning process- from analysis of the situation, through development of marketing strategy and program toward implementation (Aaker et al, 2007, p. 9). Marketing process as a whole can be explained in five consecutive stages, where the first of them is described as understanding
Abstract: The consumer market in Macedonia and the chocolate market in particular, are overtaken from many foreign brands. The domestic companies, disregarding their size, are losing market share to the competitors with stronger strategies. This paper shows the existing weaknesses in the current strategies of the domestic companies through case study of the 2 largest confectionery producers in Macedonia on one side, and discovers the consumer behaviour and preferences toward FMCG and chocolate through market research and analysis of a purposive statistical sample of 300 consumers on the other. The applied research techniques for the need of the consumer research were questionnaires and indepth interviews with the firms' managers. The analysis clearly indicates that with the adequate market research, i.e. implementation of the market research models and techniques a basis for competitive and successful marketing strategy can be created, not only by large corporations, but by individuals/owners of small and medium sized companies as well.

Key words: marketing research, market research, consumer analysis, marketing strategy. 
of the market and the needs and wants of the consumers (Kotler and Armstrong, 2008, p. 5).The subject of marketing research depending on the aims can be a number of internal and external variables. "Any research should contribute to aligning marketing strategies and marketing programs to the needs and opportunities on the market on one side, and the resources and capabilities of enterprises, on the other." (Stankovic and Djukic, 2009, p. 55). In marketing theory and practice a wide spectrum of issues can be the subject of marketing research: 1 . Research of opportunities in the market (research of market potential, consumer behaviour, competition, potential of sales and market share, etc.); 2. Research of the product (dimensions of the production program, individual products and brand equity, research of the need for new products); 3. Research of prices (factors affecting their formation and opportunities for differentiation); 4. Research of marketing channels (factors influencing their choice, the location and physical distribution); 5. Research of marketing communications (forms and media of communication). „Depending on the objectives, the research can include all these issues, or just some" (Stanković and Djukic, 2009, p. 56). Kinnear and Taylor (Cited in: Stankovic and Djukic, 2009, p. 56) explain the subject of marketing research as: 1 . Situational analysis or marketing environment research (characteristics and market potential, competition, etc.) 2. Research of marketing mix; and 3.Researchof marketing and company performance (e.g. analysis of market share, customer satisfaction and loyalty, brand value and relationship marketing, etc.).

This paper analyses market research as one of the subjects of marketing research, which means: market size estimation, market characteristics and environment analysis, analysis of the consumer behaviour, future trend analysis, etc. In other words, this paper states that market research should bean imperative for any company that wants to find out more about its current and potential customers, their desires, needs and wants and where, how and when do they express them. The importance of market research is highlighted through its key role in generating marketing intelligence and thus, making a crucial business decisions, from new market entrance to placing the products on the shelves.

With the help of market research marketers can successfully develop databases, which are essential for four reasons (Williams, 2004, p. 20): to personalize marketing communications; to improve services for consumer; to understand consumer behaviour; to make more effective marketing and social activi- ties of the organization. Decisions that use market research as navigation come down to expansion of the operations of an enterprise. Market research can contribute to the expansion of operations in several different ways: increase of market share of the company through a new way of selling existing products in the portfolio of existing consumer markets, through examination of satisfaction/dissatisfaction of consumers, researching of adequate alternative means of promotion, testing of conditions and the likelihood to purchase products from potential customers, examining the probability of creating new use of existing products and so on. Market research through market analysis should include the following areas: the target market (size, segments, growth rate, existing and future trends), customers (demographic, geographic, psychographic characteristics, needs and wants), competition (identification of the direct and indirect competitors, strategies, market share, volume of sales) (Hague, 2006, pp. 22-24).

Confectionery companies are constantly struggling to catch the attention of consumers, with improvements of the quality of products, making the package more attractive, promoting it in a more interesting way etc. Many companies in Macedonia identify their competitors from industrial point of view, but instead of this narrow view, the company should identify its competitors from a market perspective, where the focus is shifted from companies that offer products that are near each other on companies that strive to meet the same consumer group. It is often the case that companies have a false idea about current market conditions, such as believing that they are producing the best quality in the industry, supporting the general opinion that customers prefer companies with full product lines, that sale force is the only worthy marketing tool or that price is the key factor for purchase and building a strong brand is not an imperative. Such understanding of the market must be revised, because only through meeting the real needs and desires of the consumer the company can eventually become the market leader. The experience of the countries with a long market tradition guarantees the significance of market research, especially in fast moving consumer goods such as food products, or chocolate in particular, as a key element for achieving business success.

The need to save time and money in terms of research and still obtain both quantitative and qualitative data on consumers forces the company to make a choice between many different kinds of methods for collecting primary data. In fact, particular for business to consumer businesses for obtaining quantitative 
data the method of structured questionnaires can be applied, for qualitative data - method of focus groups, while for experiments with new products and their chances of success once placed on the market - test marketing, i.e. test - market $^{1}$.

\section{METHODOLOGY}

This work is presented in order to assist chocolate sales and marketing staff of companies in tailoring a marketing strategy for repositioning on, or entering on the Macedonian chocolate market, by providing the first step in the process - information gathered with market research.

The scientific aim of the paper is to offer objective, complete and systematic scientific description of the addressed subject of marketing, i.e. market research, as a first step in the process of conceiving and developing a marketing strategy. This aim is enriched with the pragmatic objective of the paper, covering the social dimension of the usefulness of the results of this research, presented through detection and application of the most effective models for strategic analysis of the market, which lead to the discovery of the factors that affect the improvement of the competitive market position.

The research is based on two primary hypotheses:

1. Market research provides a detailed understanding of the environment and industry in which the company operates;

2. Market research reveals the needs and desires of the end consumers.

The information contained in this paper was collected with primary and secondary research. Primary research was constructed as a follow up consultation with 40 both domestic and foreign companies from the industry ${ }^{2}$ through telephone interview and electronic questionnaires sent via e-mail and on-site examination of the retail environment. The consumer research was carried out with the technique of personally distributed structured questionnaires. Regarding consumer, the statistical sample used in

\footnotetext{
${ }^{1}$ The choice of methods has been made due to the conducted research and comparison of different research methods, having in mind the various questions that had to be answered in order to create a marketing strategy for the $\mathrm{B} 2 \mathrm{C}$ businesses from the confectionery industry.

${ }^{2}$ Kraskomerc Ltd, JSC Evropa - Skopje, JSC Vitaminka - Prilep, SwissLion Ltd. - Skopje, Evropa Ltd. - Shtip, Makpromet Ltd. - Shtip, Multikrem Ltd. - Shtip, Stel Impeks Ltd. - Shtip, Lion Ltd. - St. Nikole, Zito Leb - Tetovo, Via Cok ltd. - Tetovo etc.
}

the research was intentional sample of 300 units. The questionnaire was designed in a way to provide both quantitative and qualitative information about consumer preferences, needs, attitudes and feelings toward chocolate as a product and the chocolate market and industry in general. With the secondary research data were gathered from relevant trade, business, and government sources, as well as company literature and corporate annual reports. The analysis of the data was executed with the help of Microsoft Office Excel.

\section{ANALYSIS OF THE CHOCOLATE MARKET AND INDUSTRY IN MACEDONIA \\ CHARACTERISTICS OF THE CHOCOLATE MARKET IN MACEDONIA}

Food production is of strategic interest for every country. Therefore the organization of food producers and advocacy of their interests for the purpose of providing and promoting food production and increasing competitiveness is of particular importance. Confectionery industry (production of chocolate, candy, cookies, waffles, cream and chewing gum) is an important part of the food industry which, with its quantum of production (industry that finalizes materials such as flour, sugar, vegetable oil, milk, cocoa, and others) employs a significant number of workers. It is a large consumer of packaging from domestic manufacturers; it uses the domestic transport services, and plays a significant part in the trade of food products. This industry has a positive impact on the foreign trade balance of the state, because the value of exports of finished confectionery products is nearly $10 \%$ of the total export of food products (http://www.mchamber.org. $\mathrm{mk}$ ). The available capacity in ex - Yugoslavia amounted to 33,000 tons and were designed and built for the highly protected market of 24 million consumers of the Former Yugoslavia. With the production of over 24,000 - 28,000 tons annually in 1991, the available capacities were used on average of $70 \%$ annually, and in certain periods of the year to $90 \%$ (Christmas and other holidays). In the period after the ex - Yugoslavia, the unfavourable socio - political events, economic blockades from the north and south have narrowed the Macedonian market and a permanent decline in production from year to year was inevitable. In the period from 1992 to 1998 production fell and remained 14,000 -16 000 tones or $45-50 \%$ less compared to 1991 , with capacity used maximum to $30-36 \%$. From 1996 the process of liberalization through free 
TABLE 1. Export - Import of Confectionery products (in tons)

\begin{tabular}{|c|c|c|c|c|c|}
\hline \multirow[t]{3}{*}{ Year } & \multicolumn{5}{|c|}{ Product } \\
\hline & \multirow[b]{2}{*}{$\begin{array}{l}\text { Candies, biscuits, } \\
\text { waffles, cookies }\end{array}$} & \multicolumn{2}{|c|}{ Export } & \multirow[b]{2}{*}{$\begin{array}{l}\text { Products made } \\
\text { from cocoa }\end{array}$} & \multirow[b]{2}{*}{ Total } \\
\hline & & Chewing gums & $\begin{array}{l}\text { Other products } \\
\text { made from sugar }\end{array}$ & & \\
\hline 2000 & 1.181 & 551 & 1.556 & 1.441 & 4.729 \\
\hline 2002 & 846 & 515 & 1.777 & 1.275 & 4.413 \\
\hline 2005 & 2.048 & 508 & 2.000 & 1.412 & 5.968 \\
\hline 2008 & 2.389 & 522 & 2.816 & 2.773 & 8.500 \\
\hline 2009 & 2.699 & 516 & 2.688 & 2.353 & 8.256 \\
\hline 2010 & 4.033 & 563 & 2.853 & 2.657 & 10.106 \\
\hline \multicolumn{6}{|c|}{ Import } \\
\hline 2000 & 7.927 & 131 & 1.190 & 2.142 & 11.390 \\
\hline 2002 & 8.170 & 120 & 1.560 & 2.430 & 12.280 \\
\hline 2005 & 9.047 & 334 & 1.942 & 2.445 & 13.768 \\
\hline 2008 & 8.789 & 301 & 1.909 & 6.272 & 17.271 \\
\hline 2009 & 7.864 & 207 & 1.741 & 7.818 & 17.630 \\
\hline 2010 & 6.710 & 141 & 1.789 & 7.648 & 16.288 \\
\hline
\end{tabular}

SOURCE: http://www.mchamber.org.mk/\%28S\%28tdxvop55ig1bkr551hz2py45\%29\%29/default.aspx?mld=130\&lld=1\&smld= 6(visited at 15.09.2011)

trade agreements began, at first among the countries of Former Yugoslavia, i.e. the region. The new market relations and the further liberalization took place much faster than the process of advancement and modernization of the domestic production, which led to a situation where domestic confectionary industry faced strong competition from foreign companies. The total annual production dropped to 12,500 tons in 2002 despite the 30 new micro entities in confectionery industry, about 50\% less compared to 1991 when it was 24,000 tons per year. Within the strategy of the EU integration processes in the past ten years, foreign trade moved and still moves within the creation of a free trade zone in the region and the EU, thus the problem of small markets was exceeded, and conditions for permanent growth of production in this area were created.

The market is defined in different ways. One of the most commonly cited definitions explains the market as „Full respect of the supply and demand that at a certain place and at a certain time affect sales of certain products (goods) and the sum of all institutions, areas and devices that provide an organized and permanent contact between buyers and vendors (Dragičevič, 1965, p. 425). The chocolate market can be analyzed through its basic characteristics: market size, market structure (products/production, players, financial dimension), market division. The chocolate market is a mature and differentiated market, which makes it difficult for marketers of chocolate products to place a unique product to the market.

Regarding the market size, the chocolate market is primarily divided according to the geographical place where the companies perform to domestic (small) and foreign (large) market, and within the domestic market they choose only the larger urban areas for the sale of their products. The most significant foreign markets for the domestic producers are the regional countries (Serbia, Montenegro, Bosnia and Herzegovina), and in last few years the EU market (Austria, Slovenia, Slovakia, etc.) and the U.S. and Australia ${ }^{3}$.From the financial aspect, the export of confectionary products in 2009 made $\$ 27.4$ million, which is $21 \%$ more than the financial exchange inflow in 2008 (http://www. mchamber.org.mk). On the side of imports, in 2010 about 17,000 tons of confectionary products were imported, worth around U.S. \$25.2 million. Market size is also determined by the upper limit of the annual market demand, which is shown through the size of the imports of approximately17,000 tons of confectionary products and the domestic production of 8000 tons destined for the domestic market. In total, the annual consumption of confectionery products in the

\footnotetext{
${ }^{3}$ The information was acquired through a personal telephone interview from the managers of several domestic confectionery companies with different company size.
} 
Macedonian market is about 25,000 tons. With the open markets through free trade agreements and over 500 million people, there is a high potential for market development and promotion, or for new investments in this business in Macedonia.

In relation with the market structure, on the side of the supply there are 50 business entities, from which $85 \%$ are micro and small companies. There is also a significant production from entities registered as craftsmen that produce mostly bakery products and homemade sweets. The demand is constructed from the total population in the country on one side, as well as the wholesalers and retailers on the other. The production capacity of the domestic confectionery industry is around 45,000 (within the projected time to work on capacity) tons annually, 16000 tons of which are accounted for the largest domestic manufacturers -JSC „Europe“ - Skopje and JSC „Vitaminka“ - Prilep, which are considered to be the strongest direct domestic competitors. Lately, under the pressure from foreign competition that enters the market with wellknown and established brands, the placement of domestic products on the domestic chocolate market is visibly reduced. The increase in export is seen as a way out, of course with constantly decreasing profitability per unit. Namely, the export in 2007 was higher for $33 \%$ than in 2006 , but in 2008 , only $11,5 \%$ higher than in 2008. The production in 2009 reached 22,000 tons, (the level of 1991), with available capacity used on the level of over $55 \%$. In addition, the total production in 2009 compared to 2008 was higher by $32 \%$, where separately by products the highest growth was in products containing cocoa (6.5 times), sweet biscuits $119 \%$ waffles $126 \%$ etc. As compared to 1998 , when the enhanced liberalization of the market started, production in 2009 was higher by $73 \%$.

According to the Euromonitor Report (http:// www.euromonitor.com/chocolate-confectionery-inmacedonia/report ) some environment features on the Macedonian chocolate market for 2009-2010 are: negative growth in most ranges in chocolate confectionery and low growth in the impulse and indulgence sector due to the global recession and the decline in consumer spending; even so, the entire sector achieved positive growth ${ }^{4}$, mostly due to the stable performance of tablets - the largest assortment within chocolate confectionery; positive growth in 2010 was recorded also in assortments such as bagged selflines/ softlines and seasonal chocolate; in 2009 45\% of the chocolate market share was occupied from three main

\footnotetext{
${ }^{4}$ Measured in retail value and volume terms
}

competitors - Kraft Foods (Milka) with market share of $16 \%$, Nestlé with $15 \%$, and Kraskomerc (Dorina) with $14 \%$; the main competitors in the impulse and indulgence sector in 2009 were Kraskomerc Ltd (10\%), Kraft Foods (7\%) and Vitaminka (6\%). The observation indicates that critical success factor for Kraft Foods is the aggressive brand development and promotional campaigns supported by the wide product and brand portfolio. On the other side, Kraskomerc and Vitaminka have a long and traditional presence on the market that began during the Yugoslavia era. In the next few years the demand for confectionery products is expected to rise again - chocolate confectionery sector - increase by a constant value $\mathrm{CAGR}^{5}$ of $5 \%$, reaching $\mathrm{MKD}^{6} 3,477$ million by 2015 , and the impulse and indulgence products sector - increase by a CAGR of 3\% reaching MKD9 billion by 2015 (http:// www.euromonitor.com/chocolate-confectionery-inmacedonia/report).

The chocolate market in Macedonia has certain drawbacks which hamper the operations of the domestic companies. Low prices on chocolate that can be found on the market usually come from the offer which is actually a chocolate substitute which is placed as chocolate. The composition of these products is based on cheaper raw materials. Another deception of consumers is fuelled by similar names of chocolates from different manufacturers, so instead of „Nestle“, the consumer can buy „Nestle“ instead of "Milka” "Mila", and besides changes in the taste of the chocolate that come from the poor quality, the improper storage of the products also causes organoleptic changes in the product. The chocolates that can be found in Macedonian market, due to the free trade agreements are placed in lower prices than the domestic products, because the raw materials used by the domestic production, especially sugar, imported from the those countries is entering with a great customs burden. That means in certain contexts unfair competition, because of the unequal conditions for production and import of the same products.

With respect to the financial dimension, the most commonly used type of finances by the domestic companies, besides their own funds, are the credits from the commercial banks, with annual interest rates from $6 \%-16 \%$. During the recession the interest rates were elevated up to $13 \%$. The companies, especially the small and medium - sized companies, have a financial aid from the Government through the Macedo-

\footnotetext{
${ }^{5}$ Compound Annual Growth Rate - CAGR

${ }^{6}$ Macedonian currency - Macedonian denars - MKD/mkd
} 
nian Bank for Development Promotion, which main objective is to promote export, by providing credits and other forms of support to the businesses: export and investment credits, insurance of claims based on performed export against short term commercial risk (http://www.mbdp.com.mk). The greatest weakness of the method of financing is the minimal usage of self -financing, due to the undeveloped capital market and the lack of foreign capital in the domestic companies.

The chocolate market in Macedonia can be divided by types of products and types of customers. Buyers of chocolate products can be divided into three categories: Wholesalers, Retailers and Individual consumers. By type of products, the chocolate market is fragmented as any other market of fast moving consumer goods (FMCG), such as: ice cream, soft drinks, cosmetics etc. A strong competition between manufacturers of confectionary products on the market is present. Based on the conducted research on entrepreneurs and consumers, Macedonian chocolate market can be divided into six parts: Market of 'boxed' chocolate; Market of ,Molded bars'; Market of ,Seasonal' chocolate; Market of ,Countlines'; Market of ,Straightlines'; Market of ,other' chocolate confectionery.

\section{MARKET TRENDS}

Following the trends that lead to changes in demand for products and services is the base of market research, and refers to detailed introduction to all of the factors that influence consumer behaviour and their decision to purchase. Nowadays, marketing of chocolate products is searching for inspiration from other segments of the food and beverage industry. Such examples are chocolates with exotic fruits, savoury touches and ethnic flavours. Chocolate product trends that boosted sales in the past - high cocoa content, for example - may not be enough and effective for driving sales in the future.

The Report Packaged facts 2010: „Chocolate Market in the U.S. - Trends and Opportunities in Premium, Gourmet and Mass Chocolate Products" (http:// www.marketresearch.com/Packaged-Facts-v768/ Chocolate-Trends-Opportunities-Premium-Gourmet-2505082/) states that "the chocolate market displayed its recession resiliency, as retail sales increased 3 percent from 2008 to reach a record $\$ 17$ billion in 2009". This trend is considered to be a consequence of the "lipstick factor"7. Chocolate can be suitable for

Economists consider that so called lipstick sales rise during periods of recessions, because is seen as a relatively inexpensive many different industries - confectionery, beverage, restaurant, hospitality and personal care, thus it is expected that the global demand for chocolate will rise in the next years. Current chocolate market trends are (O'Bornick, 2002, pp. 19-54):

- Despite the positive growth of the market of FMCG, market share of the companies is with a downward trend, because of the maturity of the industry, driven by pricing competition and growth in the number of competitors;

- Innovation of products, offering better value for the price, building and maintaining strong brand of products are the keys which boost the growth in the industry, therefore the development of new products will need to be supported by new technology, intense distribution, interactive and new packages that will attract attention;

- It is expected shifting in the demand from larger to smaller individual packages of conventional products, as a direct result of increased consumer awareness of the need for practical packaging that allow a sense of control of the size of the individual serving as part of the daily diet - a result of greater concern for the individual health care status;

- Within the European confectionery market, chocolate industry is the largest segment by value and quantity, and the fastest growing market is one of the moulded bar - chocolate.

Market analysis (Business Insights, 2008, www. scribd.com) shows that the demand for milk and bakery products and cereals is decreasing as a result of the increased demand for soft drinks and confectionery products. Also some of the main factors of change in the near future are expected to be: ethical packaging; health concerns (especially weight control); emerging markets (Asia-Pacific and Latin America). The convenience of these products continues to be a key factor of sales, having in mind the consumer lifestyle requirements that are constantly shifting in the direction of out - of home eating, less time for cooking, overtime working etc. Adding value in terms of convenience is referred to further benefits in means of savings in time and effort, health benefits, freshness, new tastes, and ethical and social benefits, satisfying specific consumer needs such as on-the-go products, products for children, for elderly people etc. The de-

purchase that can cheer people (especially women) up, and chocolate can have the same effect due to the release of some neurotransmitters, i.e. endorphins and other opiates that can help to reduce stress and lead to feelings of euphoria. 
mand for premium chocolate, gourmet boxed chocolates, dark chocolates, healthy chocolate ${ }^{8}$, organic and functional chocolates ${ }^{9}$ that fulfil the comfort factor and concerns of the greying population is expected to be a leading growth trend, especially when the economy recovers (Packaged facts, 2010, http://www.marketresearch.com/Packaged-Facts-v768/Chocolate-TrendsOpportunities-Premium-Gourmet-2505082/). The referent group of consumers - teens between the ages of 15-19 consume more candy than other age groups, thus targeting teenagers can increase sales, following buy introduction of new products in the portfolio and/ or repositioning classic items (Packaged facts, 2002, http://www.marketresearch.com/Packaged-Factsv768/Chocolate-186930/). (Vreeland, 2010) identified more active trends in the premium chocolate market:

- Craft chocolate making: a trend that follows examples of products established somewhere else in the gourmet food world, for example craft beers and specialty coffees that inspire differentiation in the production of commoditized products;

- Savoury-inspired flavours: a cross-over from the culinary scene - experiments with adding kitchen cabinet ingredients such as olive oil, bacon, cheese, curry and chipotle into chocolates, bonbons and truffles;

- Exotic flavours: experiments with umami flavors or developing products to match consumers' moods.

Macedonia can and should be competitive in the production of chocolate, but it isn't. The current situation of the domestic producers of chocolate is unenviable, thus the work of the two largest domestic producers (JSC "Evropa" - Skopje and JSC "Vitaminka" - Prilep) is characterized with the following: the companies act as market followers - imitators, without a clear marketing strategy, are operating on intuition and experience, with commercial, rather than market orientation. They don't have clearly defined mission and goals of future development. They have no marketing department, and in terms of marketing mix - no innovation in the range of chocolate products. Their products are positioned as cheap products, with medium quality, with unoriginal packaging, and are not available everywhere. The prices of chocolate products are low, and designed by the method of "costs

\footnotetext{
${ }^{8}$ Healthy chocolate is a product that is consisted of so called "better-for-you" ingredients such as lavender and blueberry.

${ }^{9}$ Functional chocolates are products that focus on the adult issues of health concerns and the environment.
}

plus", with the concept of gross margin. Promotional activities are minimal and consist of occasionally providing better positions on shelves in retail stores and reporting about opening of new stores, while other types of promotion are not or are minimally used. The distribution is very selective - only in the largest supermarkets, making the products insufficiently available for the end users. The managers believe that the most important thing is to be able to offer cheap products and not the marketing activities as such, which makes it obvious that they don't understand the marketing concept.

\section{INDUSTRY ANALYSIS (PORTER'S FIVE - FORCES MODEL)}

Various industries realize different levels of profitability which can partly be explained by the structure of the industry, defined as a market for identical or similar products and services offered to consumers. For the analysis of the industry, qualitative analysis of the competitive position and business strategy development many different models can be applied, including Porter's 5 forces model, which suggests that unattractive market/industry is the one where the combination of the impact of the 5 forces reduces profitability, and totally unattractive industry is one that is close to the model of perfect competition. The five forces ( 1 . rivalry among existing competitors; 2 . threat of substitutes; 3 . entry of new competitors; 4 . bargaining power of suppliers; 5 . bargaining power of customers) whose influence determines market attractiveness are divided into two levels, i.e. three of them are at the level of horizontal competition, and other two on the level of vertical competition, respectively (Porter, 1985, p. 225).

For the analysis of problems in business, there are several models that have been successfully used in determining the extent of the impact of the factors analyzed for a certain phenomenon. One of the frequently used in cases of high degree of uncertainty in the analysis, is the rule of thumb ${ }^{10}$. In order to make a successful analysis based on Porter's 5 forces model, it is necessary previously to determine the factors that contribute to the end result - whether and to what extent they affect the profitability of the industry. These factors are actually five previously mentioned forces, which are further divided into their sub fac-

\footnotetext{
${ }^{10}$ Business rules typically have the following form: If $<$ a number of conditions are met $>$ then $<$ a number of activities can be performed $>$.
} 
TABLE 2. Analysis of the key success factors in the chocolate industry*

\begin{tabular}{|c|c|c|c|c|c|c|c|c|c|}
\hline \multicolumn{2}{|c|}{$\begin{array}{c}\text { Key factors/ Rating by } \\
\text { importance }\end{array}$} & \multicolumn{2}{|c|}{$\begin{array}{l}\text { JSC “Evropa” - } \\
\text { Skopje }\end{array}$} & \multicolumn{2}{|c|}{$\begin{array}{c}\text { JSC “Vitaminka” } \\
\text { - Prilep }\end{array}$} & \multicolumn{2}{|c|}{ "Kraskomerc" } & \multicolumn{2}{|c|}{ "Benchmark" } \\
\hline $\begin{array}{l}\text { Key success } \\
\text { factors }\end{array}$ & Rating & Score & $\begin{array}{l}\text { Relative } \\
\text { business } \\
\text { strength }\end{array}$ & Score & $\begin{array}{l}\text { Relative } \\
\text { business } \\
\text { strength }\end{array}$ & Score & $\begin{array}{l}\text { Relative } \\
\text { business } \\
\text { strength }\end{array}$ & Score & $\begin{array}{c}\text { Relative } \\
\text { business } \\
\text { strength }\end{array}$ \\
\hline $\begin{array}{l}\text { Intensive and } \\
\text { extensive distribution }\end{array}$ & 20 & 2 & 40 & 3 & 60 & 4 & 80 & 5 & 100 \\
\hline Promotion & 15 & 1 & 15 & 3 & 45 & 4 & 60 & 5 & 75 \\
\hline Quality product & 10 & 3 & 30 & 3 & 30 & 4 & 40 & 5 & 50 \\
\hline Price & 10 & 4 & 40 & 4 & 40 & 4 & 40 & 5 & 50 \\
\hline Management & 05 & 3 & 15 & 3 & 15 & 4 & 20 & 5 & 25 \\
\hline Finances & 15 & 2 & 30 & 4 & 60 & 4 & 60 & 5 & 75 \\
\hline Customer loyalty & 10 & 2 & 20 & 3 & 30 & 4 & 40 & 5 & 50 \\
\hline $\begin{array}{l}\text { Expansion on foreign } \\
\text { markets }\end{array}$ & 10 & 3 & 30 & 3 & 30 & 4 & 40 & 5 & 50 \\
\hline Market share & 05 & 1 & 05 & 2 & 10 & 3 & 15 & 5 & 25 \\
\hline Total & 100 & & 225 & & 320 & & 395 & & 500 \\
\hline
\end{tabular}

* The matrix is constructed in a way where at first several key factors for success are determined from the managers point of view, those are ranked in importance by allocating a total of 1 or 100 points on each, then for each of the selected competitors these factors are judged by the achieved results on a scale of 1-5 (1 lowest, 5 highest), and on the end points of each factor are multiplied with the score of each competitor and the result indicates competitors relative strength in business compared to others.

tors of influence, and these are the element of analysis in order to obtain information that will formulate a strategy for the business plan. One way to determine the weight of each of the factors provided that each of the sub factors have more or less the same degree of influence and if each of the sub factors are assessed with „high“ (3), „medium“ (2) or „small“ (1) impact on increasing rivalry and decrease of the attractiveness, then subsequently the conclusion for the impact of each factor can be assessed as "high“, „medium“ or "small" according to the average of the estimates of the sub factors. With the same algorithm it can be determined which sub factors can be involved in assessing the impact of each of the factors (Jellema, \& Arons, 1997). The evaluation of the current impact of the 5 forces on the Macedonian chocolate industry profitability is based on the average of managers' opinion about the degree of current influence of each sub-factor of the 5 forces on a interval scale from $1-3$ (1-lowest, 3-highest $)^{11}$.

1. Rivalry among existing competitors $-2,38$ (High number of competitors - 3, Low market growth

\footnotetext{
${ }^{11}$ Example of the calculation of the influence of the 5 forces on industry attractiveness: , i.e.; etc.
}

rate -3 , Barriers for exit the market - 1, Fixed costs - 2, Highly differentiated products - 2, Low costs for crossing over - 3, High promotional costs -2 , Brand identity -3 );

2. Threat of substitutes -3 (High number of product substitutes -3 , Low costs for crossing over -3 )

3. The possibility of entry of new competitors barriers to enter and exit the market - 2,15 (Need for investment -2 , Availability of materials - 2, Politics and law regulations -1 , High transaction costs -3 , High promotional costs -3 , The direction of prices movement -2 , Brand power -2 , Customer loyalty and elasticity of demand- 2 , Economy of scale is needed - 3, Vertical integration is present -2 , Absolute advantage in costs is present -3 , Network effect and globalization is present - 3);

4. Bargaining power of suppliers $-2,5$ (Low concentration of suppliers -3 , High quantity of purchase per supplier - 3, High importance of raw materials- 3 , Cost of change -2 , Little number of substitutes for raw materials -3 , Power of labour organizations -1);

5. Bargaining power of customers $-2,67$ (High concentration of byers as opposed to sellers - 3; 
Degree of dependence on existing channels of distribution- 2, Great number of substitutes - 3; Consumer price elasticity - 2, Great product differentiation - 3, Great informational power of consumers - 3).

After the analysis it can be concluded that the degree of competitive intensity on the chocolate market is high $(2,6)$, which inevitably, from the point of profitability reduces the attractiveness of the market. Chocolate market is mature and fragmented market, where more profit can be achieved by increasing market share, which means that companies must lead in the fight for the end consumer. To overcome the gap that occurs in rivalry with existing competitors, it is necessary to establish a concrete strategy for market positioning of the products that will strengthen the position of the company, whilst avoiding the practice of price competition and instead, apply the product differentiation and establishing cooperation with competitors or enter into partnerships with some of the competitors. Due to the threat of substitutes the products must be differentiated from competing offers and greater value through a unique product should be offered, which will reduce the possibility of replacing the product of the company with a substitute. The possibility of entry of new competitors can be limited primarily by creating a strong domestic brand of product that will generate loyal customers. Great bargaining power of buyers and consumers can also be reduced through differentiation of products, promotion of the best value for the price to increase loyalty to the products, better customer servicing and make products more affordable through intensive distribution or increasing the number of own specialized stores. Power of suppliers should be controlled by grouping orders to receive quantity discounts, reviewing the possibilities for cooperation with producers of sugar beets in the state to avoid higher prices of imported sugar. For the analysis of the industry and market to be complete, a comparative overview of the range of competitors in terms of key success factors in a particular industry needs to be done, which shows the progress of the companies' competitors through two-dimensional matrix (Table 2).

In this example, the best ranked on all factors is the competitor „Kraskomerc“, followed by JSC „Vitaminka“ and JSC „Evropa“, but in terms of ideal standards or best practice, i.e. benchmark, all three companies should work harder to improve their performance on the market.

\section{ANALYSIS OF THE CUSTOMER PREFERENCES FOR CHOCOLATE PRODUCTS}

In order to create an effective marketing strategy, it is necessary to hear the voice of the consumer, through systematic market research. Examination of the preferences of consumers will provide insight into their tastes and buying habits, which is necessary for the successful formulation of the marketing strategy. The main objectives of the survey of consumer preferences
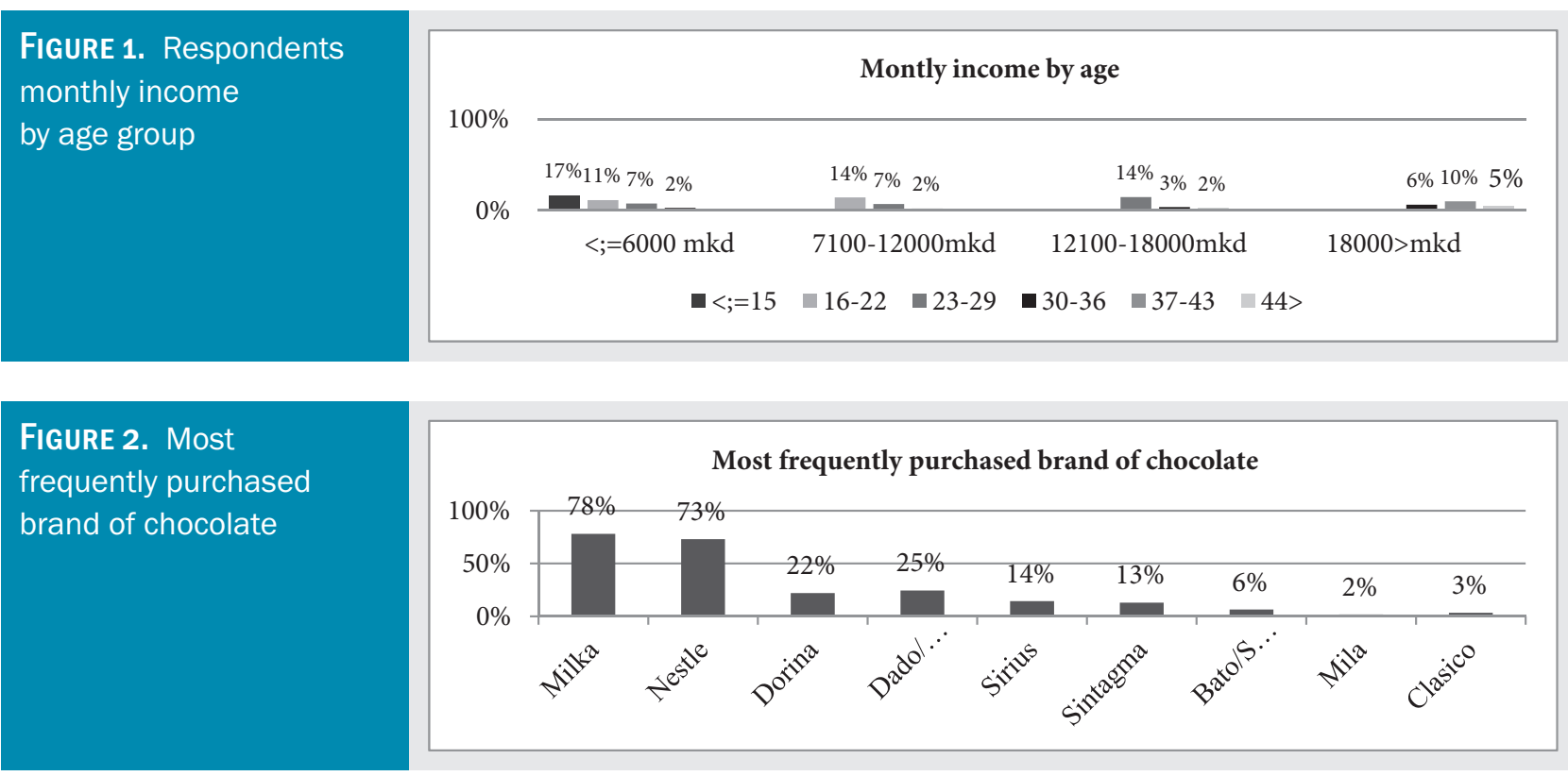
and their relation to chocolate products, carried out by questionnaire are: to learn the current patterns of consumption of chocolate products; to get consumer feed - back for the perception in terms of favourable flavours and brands of chocolates; to detect the degree of sensitivity on prices; to detect the degree of loyalty to branded products; to show the preferences for the type of distribution channels; to find out the level of awareness of products; to discover opportunities to improve existing products.

The research was conducted in October 2009, in the following cities: Shtip, Kochani, Strumica, Gevgelija, Kumanovo and Skopje. The size of the sample was 300 respondents, from which $140(47 \%)$ - male and $160(53 \%)$ - female. The age groups were $15(17 \%)$, $16-22$ (25\%), 23-29 (28\%), 30-36 (13\%), 37-43 (12\%) and over 44 years of age (5\%).

Regarding the personal monthly income, as expected, the group with the largest income were from 30 - over 44 years of age. Most of the customers (85\%) live in an urban area, i.e. the cities in a family of four (56\%) (Figure 1).

Most often bought brand of chocolate is Milka (Kraft Foods), Then Nestle (Nestle S.A.), Dorina (Kras), and the domestic products like Sirius and Sin- tagma (Vitaminka) and Mila and Clasico (Evropa) are purchased only by a small percentage of the respondents (Figure 2). The respondents also prefer brands with a foreign origin $(62 \%)$, rather than the ones with a domestic origin (38\%) for several reasons (see Figure 3), but if some factors were met, they would change the foreign with a domestic brand of chocolate (see Figure 4).

Most of the chocolate purchases are done by the age group from 15 -36 years, several times per week. The consumers buy mostly 1 peace of chocolate per purchase (88\%), $9 \%-2$ pieces, $3 \%-3$ pieces and nobody buys more than 3 pieces per purchase. When they buy chocolate, they usually buy the size of $100 \mathrm{gr}$. $(78 \%)$ and 30gr. (71\%) (see Figure 6) and then consume it most frequently in the afternoon (43\%), than in the evening (31\%) and morning (26\%).

The main reasons that make customers buy chocolate are as presented in Figure 7. - giving it away as a gift, the need for something sweet, as a source of energy, other special occasions - birthday, holiday etc., and because it is good for the health, and most of them prefer the taste of a milk chocolate $(67 \%)$, waffles and biscuits filling (56\%), caramel (54\%), nuts and almonds filling (54\%) (see Figure 8).
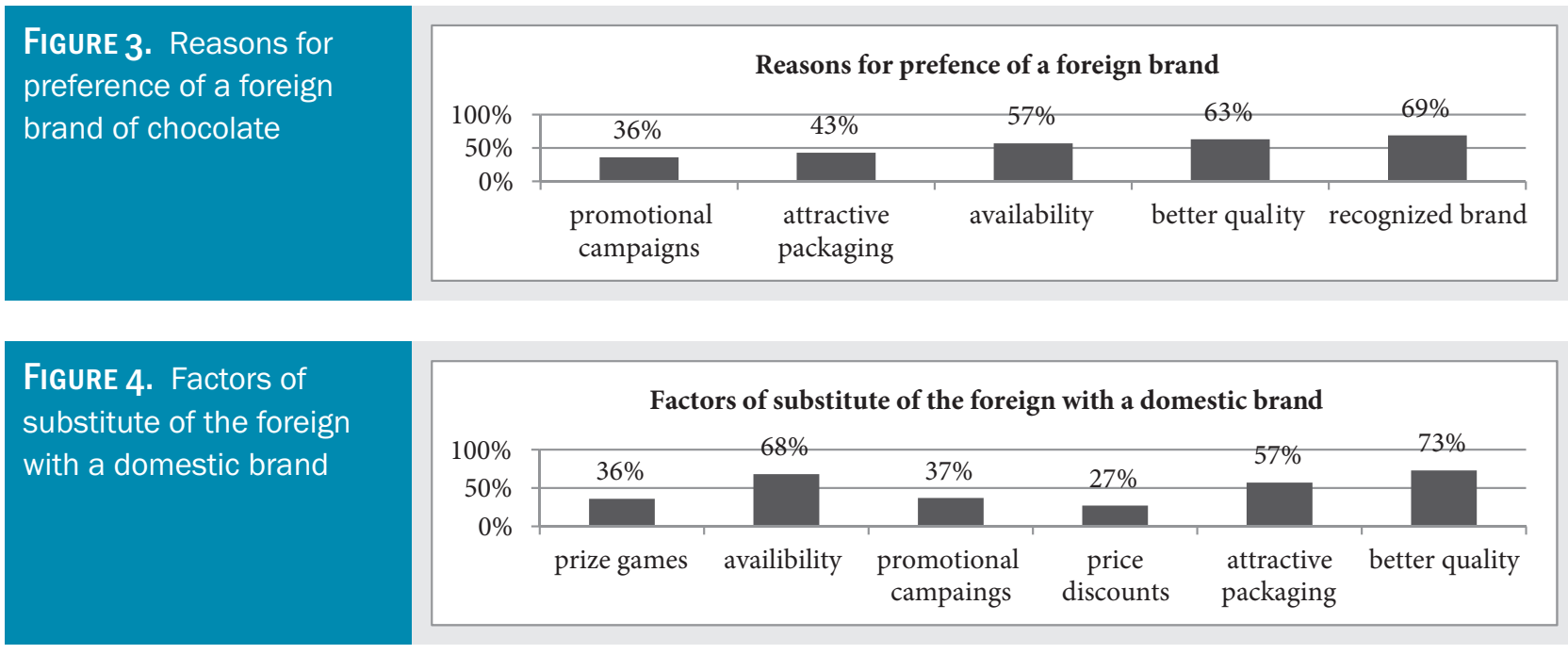

FiguRE 5. Frequency of chocolate purchase by consumers' age group

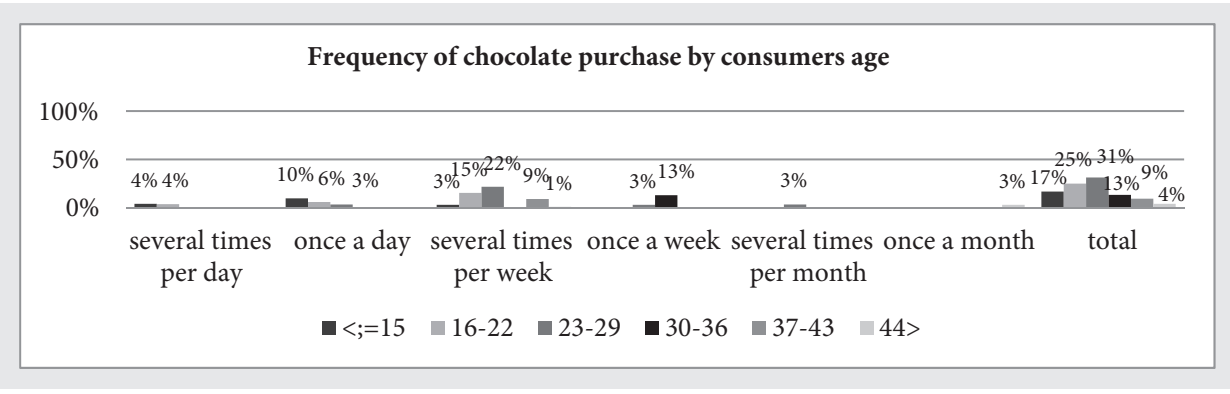



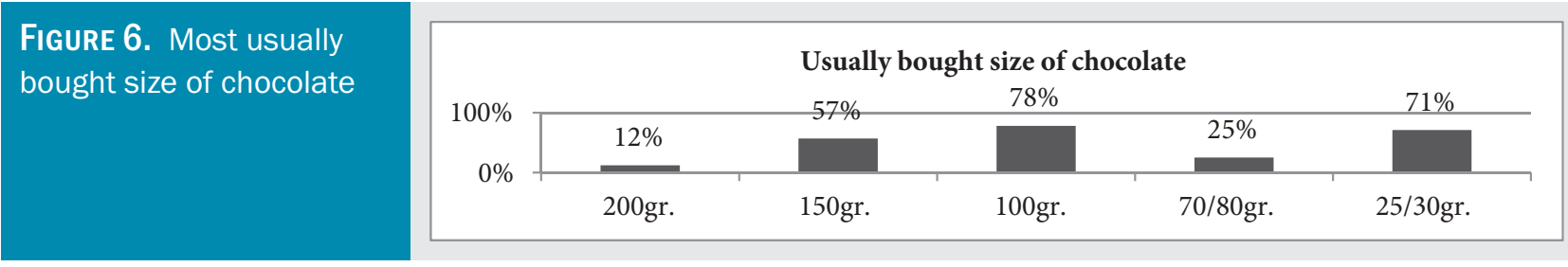

FigURE 7. Main reasons

that make customers

buy chocolate products
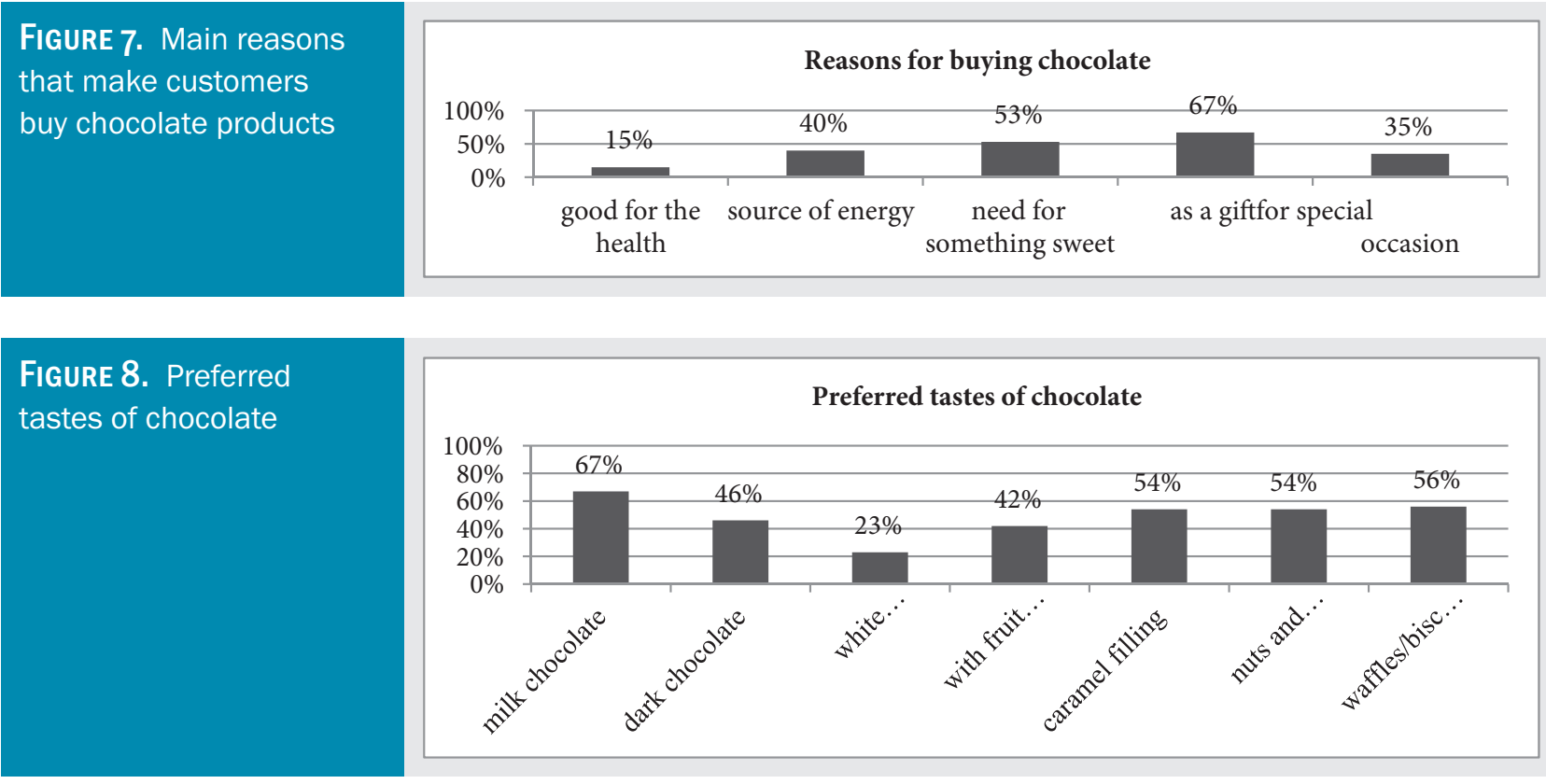

FigURE 9. Rating of the

characteristics of the

domestic chocolates

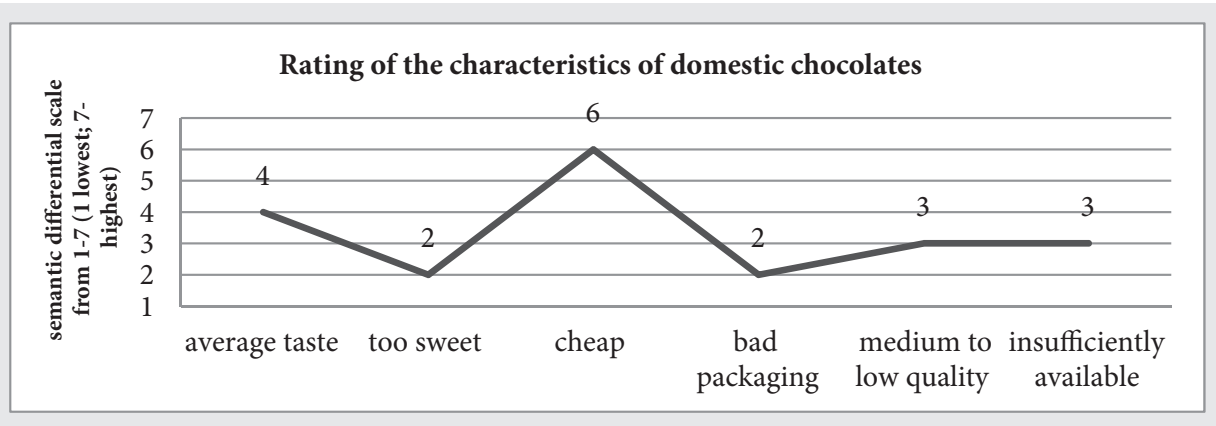

The domestic chocolates are characterized with an average taste, low prices but also medium to low quality, too sweet on taste, with a bad and unattractive packaging and insufficiently available in stores (Figure 9). The average rate on sematic differential scale from $1-7$ ( 1 - lowest rate; 7 - highest rate) is $3,3^{12}$.

\footnotetext{
${ }^{12}$ Semantic differential scale is composed form more bipolar scales with certain terms related to a product ranked from $1-7$ (1 -lowest, 7 - highest), which measure the behavior and feelings of consumers towards a particular subject, and allows comparison of the attitudes scale for several different items of the same species, to identify differences between them. The data are analyzed by calculating the arithmetic mean for each group of opposite adjectives, after which the aggregate results are applied to the scale and the comparison is made.
}

According to the respondents' opinion, the most important attributes for chocolate products are the taste, the quality and the communication with the end consumer, as well as the chocolate filling, the availability in stores and the packaging. The price is not among the top ranked attributes. When asked about the appropriate price for chocolate products, in some cases the consumers would pay more for the product than the current market price (see Figure 11/Table 3).

When formulating the market price, the opinion of the consumers should be taken into consideration. The price elasticity of demand for chocolate products 

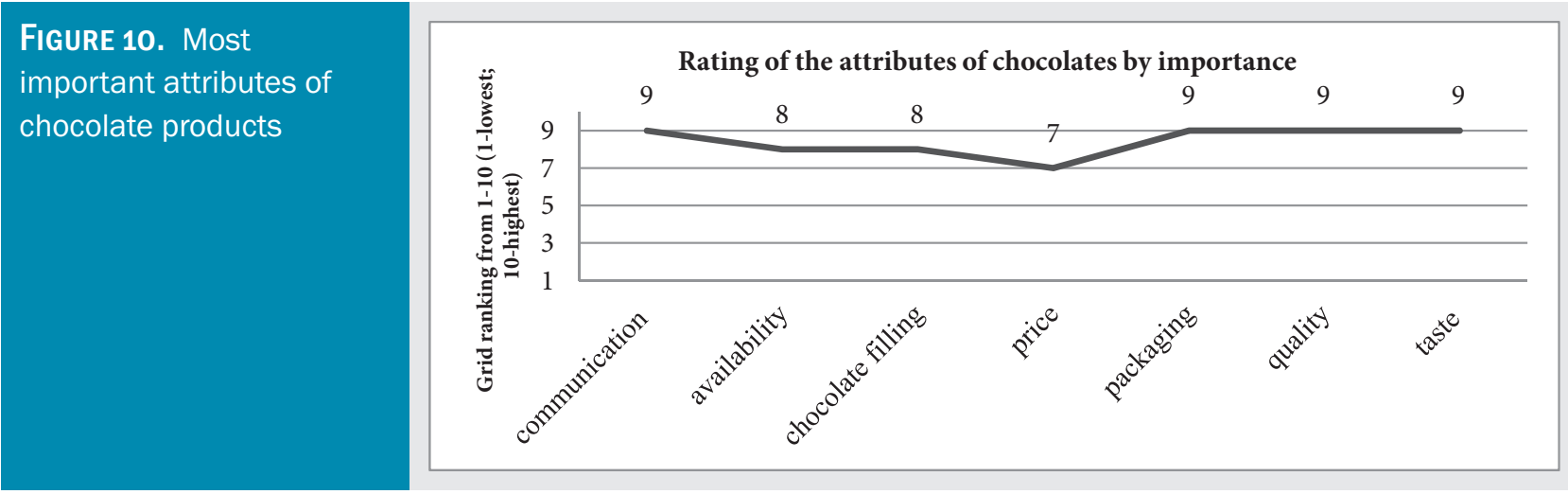

FiguRE 11. Appropriate

price of chocolate

by weight/size

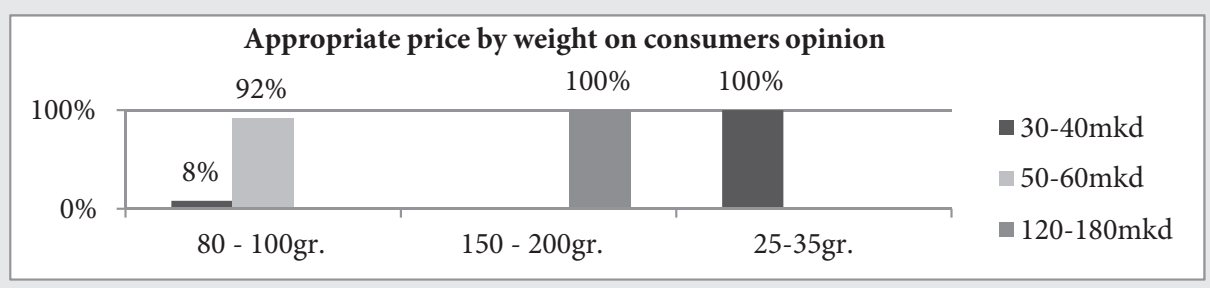

is less than $1^{13}$, which under the rule of thumb is considered as inelastic demand. If the price of the favourite brand of chocolate is increased by $10-15 \%, 91 \%$ of 300 consumers will continue to buy it, and only $9 \%$ of respondents would buy another brand of chocolate (see Figure 12).

\footnotetext{
${ }^{13}$ Price Elasticity of Demand $(\mathrm{PEOD})=(\%$ Change in the required amount $) /(\%$ change in price $)=(0,09) /(0,11)=-0,81$ $=0,8<1 ; \%$ Change in the required amount $=$ (amount of new claims - amount of old claims $) /$ amount of old claims $=(274-$ $300) / 300=-0,087=-9 \% ; \%$ Change in price $=($ new price - old price $) /$ old price $=(42-38) / 38=0,105=11 \%$. When calculating the price elasticity of demand the negative values are ignored and the positive value is taken into consideration.
}

In case the price of the favourite brand of chocolate to be reduced by $10 \%$, only $8 \%$ of 300 consumerswouldbuyat least twice, and the others wouldn't be affected by it, which also indicates on the price in elasticity of these products (see Figure16) ${ }^{14}$.The respondents prefer fashionable $(74 \%)$ or retro $(72 \%)$ design of the product and packaging, the most attractive colour for the packaging is black (56\%), purple (45\%), red (43\%) or combination of those (64\%), while green and blue are not considered to be very attractive. Consumers often, in descending order, buy chocolate at the ne-

\footnotetext{
${ }^{14} \mathrm{PEoD}=(\%$ Change in the required amount $) /(\%$ change in price $)=(0,08) /(0,11)=0,7<1$
}

TABLE 3. Price differences among brands and among market price and suggested price by customers

\begin{tabular}{|c|c|c|c|c|c|c|}
\hline $\begin{array}{l}\text { Brand of } \\
\text { chocolate }\end{array}$ & Weight & $\begin{array}{c}\text { Average } \\
\text { market } \\
\text { price }\end{array}$ & $\begin{array}{c}\text { Price } \\
\text { differences } \\
\text { among } \\
\text { brands }\end{array}$ & $\begin{array}{c}\text { Price } \\
\text { differences } \\
\text { among } \\
\text { brands (\%) }\end{array}$ & $\begin{array}{l}\text { Price differences } \\
\text { among market } \\
\text { price and } \\
\text { suggested price } \\
\text { by customers } \\
\text { (50/60mkd) }\end{array}$ & $\begin{array}{l}\text { Price differences } \\
\text { among market } \\
\text { price and } \\
\text { suggested price } \\
\text { by customers } \\
\text { (50/60mkd) (\%) }\end{array}$ \\
\hline Clasico & 100gr. & $35 \mathrm{mkd}$ & - & - & $15 / 25 \mathrm{mkd}$ & $43 / 71$ \\
\hline Milka & $100 \mathrm{gr}$. & $55 \mathrm{mkd}$ & $20 \mathrm{mkd}$ & 57 & $5 \mathrm{mkd}$ & 9 \\
\hline Nestle & 100gr. & $55 \mathrm{mkd}$ & $20 \mathrm{mkd}$ & 57 & $5 \mathrm{mkd}$ & 9 \\
\hline Dorina & 100gr. & $50 \mathrm{mkd}$ & $15 \mathrm{mkd}$ & 43 & $10 \mathrm{mkd}$ & 20 \\
\hline Gorenjka & 100gr. & $45 \mathrm{mkd}$ & $10 \mathrm{mkd}$ & 29 & $5 / 15 \mathrm{mkd}$ & $11 / 33$ \\
\hline Najljepše Želje & 100gr. & $35 \mathrm{mkd}$ & - & - & $15 / 25 \mathrm{mkd}$ & $43 / 71$ \\
\hline dado/goga & 100gr. & $35 \mathrm{mkd}$ & - & - & $15 / 25 \mathrm{mkd}$ & $43 / 71$ \\
\hline Bato/Seka & 100gr. & $35 \mathrm{mkd}$ & - & - & $15 / 25 \mathrm{mkd}$ & $43 / 71$ \\
\hline
\end{tabular}



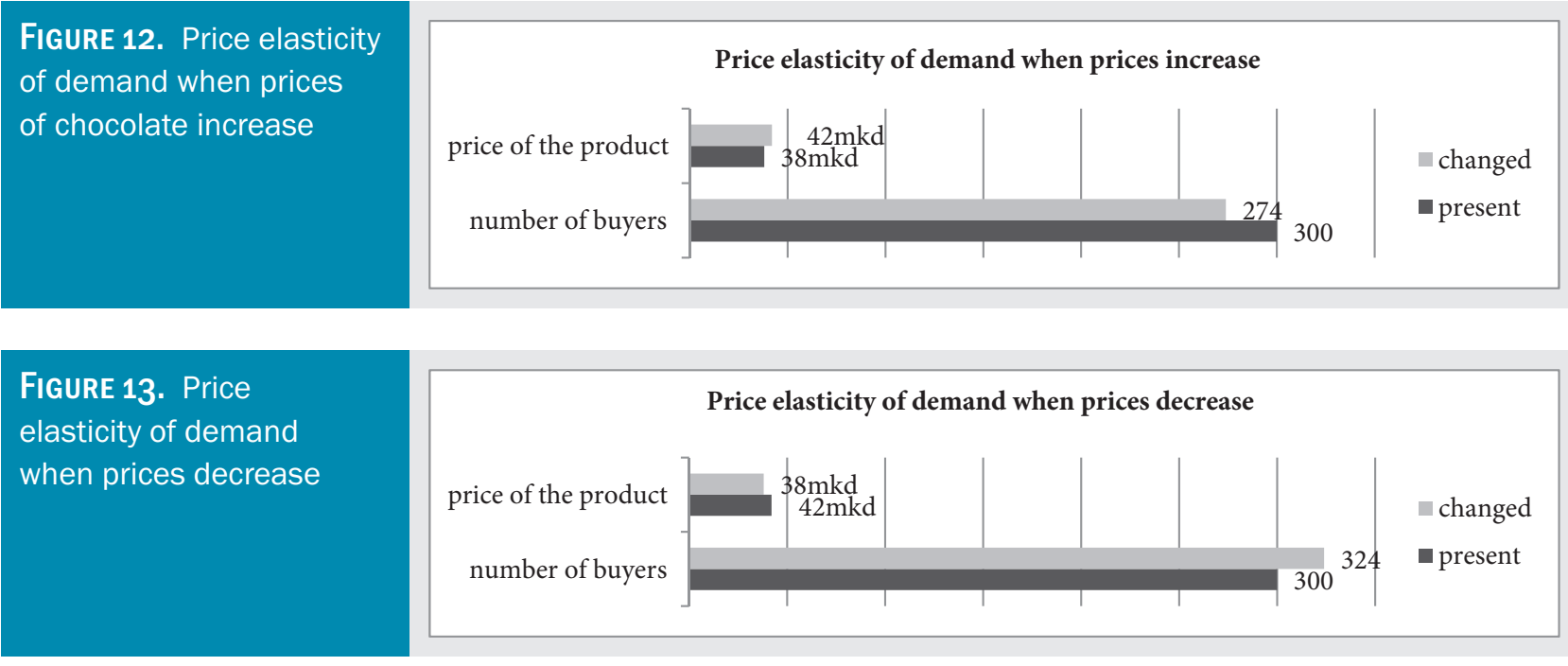

FiguRE 14. Alternative locations for the

placement of chocolate products in consumer preference

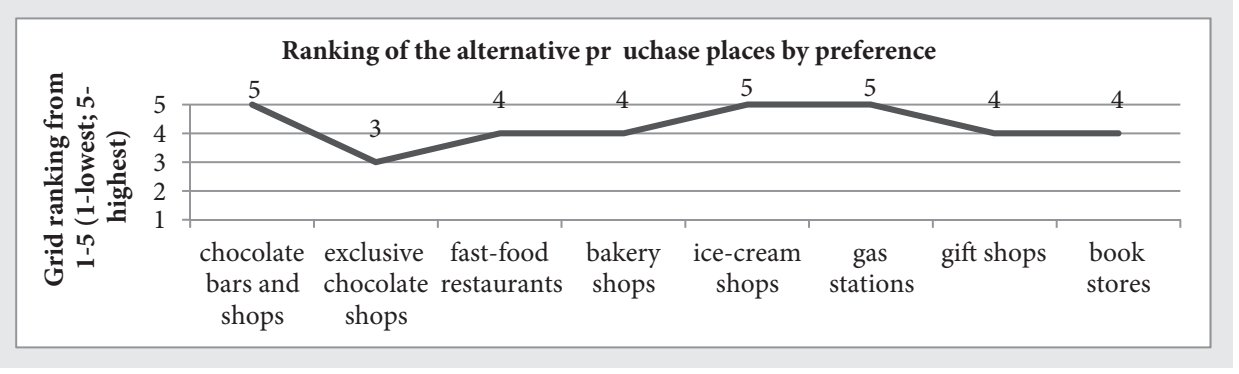

arest local store (100\%),discounts (67\%),super and hypermarkets (48\%),and less in kiosks (44\%) and in specialized stores (35\%). In case of insufficiently availability of a brand in stores, most of the consumers $(88 \%)$ will buy another brand of the same product or a substitute product. Respondents have also shown interest in new possible places for chocolate purchase, rating them on a scale from 1-5 (1 - lowest; 5 highest) by preference (see Figure 14).

A great deal of the respondents (47\%) buy more chocolate as a result of sale promotion, and the most recallable ads are the ones of Milka chocolates - "Tender pleasure" (78\%), Dorina - "Dorina - full cull" (45\%), Snickers - "Don't stop, grab Snickers"(43\%), Kinder chocolate - "Ideal combination of milk and chocolate" (38\%). Consumers like the ads for more reasons that affect the degree to which the ad is been noticed and remembered - connection with reality (86\%), interesting topic, actors and music (67\%), innovative design (54\%) and elements of humour (35\%).The consumers are not satisfied with the current market situation regarding the offered poor choice of domestic brands (88\%), the limited choice of branded products (34\%) and the narrow choice of chocolate tastes (24\%). General conclusions from the conducted survey of the consumers of chocolate, which can be used in the formulation of a marketing strategy, are:

- All respondents consume Chocolate, regardless of age, gender, economic power and place of residence; Chocolate is a product with impulsive and inelastic demand and is considered as a good gift item, which is usually given to children and friends;

- Preferences regarding the product are - availability - in the nearest shops, size of $100 \mathrm{gr}$ and smaller packages of 35gr, original modern or retro design of the packing, with a combination of colors, a certain level of quality and good taste, mostly milk chocolate;

- Chocolate is purchased multiple times during the week, one product per purchase, and is usually consumed in the afternoon or evening;

- Most consumers have a high rate of remembrance for the ads of Milka chocolates - linked to real life, with elements of emotion;

- The category of these products doesn't enjoy very high level of brand loyalty and consumers are willing to try something new; 
- The idea to make chocolate available at gas stations, ice cream shops, bakery shops, bars and restaurants and cafes, etc. is evaluated positively;

- Scarce domestic brands.

\section{CONCLUSION}

Marketing research in the company raises the question of providing solutions for existing and future problems, and helps the company in transferring the operations from the current position into the desired future position, thus achieving the desired end results. The need for marketing research and market research in specific is motivated by the need to set the strategy direction, to enable the company to manoeuvre through turbulent business environment. It is necessary to rationally use resources and to promote coordinated development of the ongoing activities, i.e. to trace the development and the way of its accomplishment. The necessity of market research is confirmed as a function of the strategy that provides an efficient and effective decision making on a particular market. Market research is found to be one of the key instruments of marketing - management used to find, collect and analyze basic data that lead to valid information for decision making and increase competitive advantage. The significance of market research essentially stems from changes in business conditions that lead to technological change, increasing complexity of managerial work, increasing complexity of the external environment, increasing the spread between decisions and outcomes. The need of enriching the knowledge and enabling managers to possess the right information at the right time, which helps in creation of a business unit strategy or corporate strategy in general calls for devoted action of changes in the managerial way of thinking and therefore the way of doing business. Food industry is an industry that intensively and in large amounts invests in market research. The research in the Macedonian chocolate industry and market confirms that the domestic companies have a lack of market information featuring: customer needs, requirements and preferences; market size; market potential; market growth; the available and suitable types of research techniques; etc. This situation results in a vague business strategies and weak market position in relation to foreign competitors with a market orientation in their work. Changes in the operations of the domestic companies can be made with the proper use of market research for obtaining all the necessary information about the chocolate market (size, potential growth, profitability of a particular market/industry, consumer preferences). The companies can choose from a variety of techniques for analysis of technological, economic, political, legal, sociological, cultural factors outside the company environment (PEST/EL, SLEPT, Porter's 5 - forces model) and internal company factors - strengths and weaknesses (SWOT, Six Sigma Marketing, etc.). Nevertheless, in a market oriented company, the primary focus is on the end consumer and therefore the consumer analysis should be one of the pillars in market research and marketing activities in general. The unquestionable role of market research is presented simply through providing the basis for the creation of a competitive marketing strategy, which further on leads the way of the company on the target market.

\section{References}

1. Aaker, D. A., Kumar, V., Day, G. S. (2007), Marketing Research, $9^{\text {th }}$ Edition, John Wiley\&Sons, Inc.

2. Business Insights (2008), Future Convenience Food and Drinks - New opportunities in a developed market, www.scribd.com (visited at 8.08.2009)

3. Dragičevič, A. (1965), Leksikon političke ekonomije II, Zagreb: Informator.

4. Hague, P. (2006), B2B International - A Practical Guide to Market Research, Grosvenor House Publishing Ltd.

5. Jellema, M., Arons, S. (1997), An Object Oriented Model of an Industrial Enterprise and its Environment, Proc. European Simulation Multiconference 1997 (The Society for Computer Simulation International), Istanbul.

6. Kotler, P., A. G. (2001), Principles of Marketing, Third European Edition, Pearson Education.

7. Kotler, P., A. G. (2008), Principles of Marketing, $12^{\text {th }}$ Edition, Pearson Education.

8. O'Bornick, M. (2002), Growth Strategies In Packaging Food And Drink To 2007: Identifying the key market sectors, Business Insights Ltd. 
9. Porter, M. E. (1985), Competitive Advantage: Creating and Sustaining Superior Performance, Free Press, New York.

10. Packaged facts, (2010), Chocolate Market in the U.S.: Trends and Opportunities in Premium, Gourmet and Mass Chocolate Products, MarketResearch. com - Packaged facts, http://www.marketresearch. com/Packaged-Facts-v768/Chocolate-TrendsOpportunities-Premium-Gourmet-2505082/ (visited at 05.07 .2011 )

11. Packaged facts (2002), The Chocolate Market, Packaged facts - a division of MarketResearch. com http://www.marketresearch.com/PackagedFacts-v768/Chocolate-186930/ (visited at 05.07.2011).

12. Riderstrale J., K. N. (2002), Funky business, Book House Publishing.

13. Stanković Lj., Đukić S. (2009), Marketing, Ekonomski fakultet, Niš.

14. State Statistical Office of Macedonia (2008), Publication - Macedonia innumbers2008, Skopje.
15. State Statistical Office of Macedonia. (2009). Publication - Macedonia innumbers2009.Skopje.

16. Vreeland, C. (2010), Chocolate Market in the U.S.: Trends and Opportunities in PremiumGourmet and Mass Chocolate Products, Packaged Foods, MarketResearch.com.

17. Williams, J. (2004), CIM revision cards. Marketing research and Information, Elsevier Ltd.

18. http://www.euromonitor.com/chocolateconfectionery-in-macedonia/report (visited at 16.06.2011)

19. http://www.marketingpower.com/AboutAMA/Pages/ DefinitionofMarketing.aspx (visited at 15.03.2012).

20. http://www.mbdp.com.mk/en/index.php (visited at 10.05.2011)

21. http://www.mchamber.org.mk/\%28S\%28td xvop55ig1bkr551hz2py45\%29\%29/default. aspx?mId=130\&lId=1\&smId=6 (visited at 15.09.2011)

22. http://www.stat.gov.mk/PrikaziSoopstenie. aspx?rbrtxt $=42$ (visited at 13.19.2011)

\section{Rezime}

\section{Marketing istraživanje tržišta čokolade u Makedoniji}

Tamara Jovanov Marjanova

Tržište potrošnih dobara u Makedoniji, a posebno tržište čokolade, preuzeto je od strane brojnih stranih brendova. Domaće kompanije, bez obzira na svoju veličinu, gube tržišno učešće u odnosu na konkurente sa jačim strategijama. Ovaj rad ukazuje na postojeće slabosti aktuelnih strategija domaćih kompanija putem studije slučaja 2 najveća proizvođača konditorskih proizvoda u Makedoniji, $s$ jedne strane, i otkriva ponašanje potrošača i njihove preferencije na tržištu potrošnih dobara i čokolade putem marketing istraživanja i analize namernog uzorka od 300 potrošača, $s$ druge strane. Primenjene su istraživačke tehnike za potrebe istraživanja ponašanja potrošača u vidu upitnika i dubinskih intervjua sa menadžerima kompanija. Analiza jasno pokazuje da adekvatnim marketing istraživanjima, npr. implementacijom modela i tehnika istraživanja tržišta, baza za konkurentnu i uspešnu marketing strategiju može biti kreirana, ne samo od strane velikih korporacija, već isto tako i od strane pojedinaca / vlasnika malih i srednjih preduzeća.

Ključne reči: marketing istraživanje, istraživanje tržišta, analiza potrošača, marketing strategija. 